\title{
Berat beban tas dengan keluhan musculoskeletal pada siswa SMA
}

\author{
Yunita Sari Purba*, Putri Winda Lestari
}

Prodi Keselamatan dan Kesehatan Kerja, Fakultas Kesehatan Masyarakat, Universitas Binawan

*Email: yunita@binawan.ac.id

\section{Schoolbag-weights and musculoskeletal complaints among high-school students in Jakarta, Indonesia}

Background: Most of high school students every day carry a schoolbag-weights of approximately $5-7 \mathrm{~kg}$ from home to school within 3 years study time, it can trigger the emergence of Musculoskeletal disorders (MSDs), which is a collection of symptoms / disorders related to muscle tissue, tendons, ligament, cartilage, nervous system, bone structure, and blood vessels. MSDs can cause disruption of daily activities, concentration of learning, and learning achievement.

Purpose: To determine the effects of School Bag-weights and musculoskeletal complaints among high-school students in Jakarta, Indonesia.

Method: An analytic observation with cross-sectional approach. The population was all high school students at east Jakarta with the sample student in grade XI of 370 students and taken by simple random sampling. The independent variable is the Schoolbag-weights, while the dependent variable is MSDs. Retrieval of data by filling out the Nordic Body Map questionnaire. Data processed univariate and bivariate with the Spearman test.

Results: There was an effect of schoolbag-weights and musculoskeletal complaints among high-school students in Jakarta, Indonesia. Spearman correlation analysis results, got $p=0.000$ with $r=0.225$, which means there is a weak correlation between schoolbag-weights with musculoskeletal complaints. The direction of the positive correlation that means the heavier the schoolbag that they carry would follow by a higher the musculoskeletal complaints, and vice versa.

Conclusion: There is a correlation between school bag-weights and musculoskeletal complaints among highschool students in Jakarta, Indonesia

\section{Keywords: Schoolbag-weights; Musculoskeletal complaints; High-school students}

Pendahuluan: Siswa SMA setiap hari memikul beban pada bagian tubuh belakang kurang lebih 5-7 kg setiap selama jangka waktu 3 tahun selama studi, hal tersebut dapat memicu munculnya Musculoskeletal disorders (MSDs) yaitu sekumpulan gejala/gangguan yang berkaitan dengan jaringan otot, tendon, ligament, kartilago, sistem saraf, struktur tulang, dan pembuluh darah. MSDs dapat menyebabkan gangguan kegiatan sehari-hari, konsentrasi belajar dan prestasi belajar.

Tujuan: Mengetahui seberapa besar berat tas berpengaruh terhadap risiko musculoskeletal disorder.

Metode: Analitik observatif dengan pendekatan cross-sectional. Populasi adalah seluruh siswa SMA di wilayah Kec. Kramat Jati Jakarta Timur sebanyak 4.708 siswa dengan sampelnya siswa kelas XI sebanyak 370 siswa, diambil secara simple random sampling. Variabel bebas adalah berat tas sedangkan variabel terikat adalah MSDs. Pengambilan data dengan pengisian kuesioner. Data diolah secara univariat dan bivariat dengan uji korelasi spearman.

Hasil: Didapatkan korelasi antara berat tas dengan musculoskeletal disorder. Hasil Analisis Korelasi Spearman antara berat tas dengan keluhan nyeri otot, didapatkan nilai $p=0.000$ dengan nilai $r=0.225$ yang artinya terdapat korelasi yang lemah antara berat tas dengan keluhan nyeri otot. Arah korelasi positif menunjukkan bahwa semakin berat beban tas maka keluhan nyeri otot makin tinggi, begitu juga sebaliknya.

Simpulan: Berat beban tas berkorelasi dengan keluhan Musculoskeletal disorders (MSDs).

\section{Kata kunci: Berat Tas; Musculoskeletal Disorder; Siswa SMA}




\section{PENDAHULUAN}

$\mathrm{Di}$ Indonesia, ditemukan adanya kecenderungan munculnya musculoskeletal disorder pada anak usia sekolah dikarenakan pertumbuhan tulang yang belum matang, sehingga kebiasaan-kebiasaan yang tidak baik akan mempengaruhi pertumbuhan tubuh, misalnya posisi membaca, menulis, dan duduk yang tidak ergonomis. Sikap tubuh yang salah ketika duduk, berdiri, tidur, atau ketika membawa beban yang terlalu berat dapat menyebabkan gangguan pada tulang belakang dan persendian, sehingga dapat menimbulkan rasa pegal pada beberapa bagian tubuh. (Nurhaliza, 2020)

Dalam kegiatan belajarnya, siswa menggunakan tas untuk membawa beban buku maupun alat tulis. Terdapat berbagai jenis tas, namun tas ransel dianggap sebagai cara yang nyaman dan aman untuk membawa beban. (Navuluri \& Navuluri, 2018). Batas berat beban tas punggung yang diperbolehkan untuk dibawa yaitu tidak boleh lebih dari $10-15 \%$ dari berat orang tersebut. Jika beban yang dibawa melebihi $15 \%$, maka hal ini dapat menyebabkan siswa tersebut mengalami keluhan musculoskeletal, beban berat tas tersebut akan menekan otot, ligamen serta tendon sehingga terjadi ketegangan dan menyebabkan timbulnya nyeri akut pada leher (American Chiropractic Association, 2018).

Sebagian besar siswa menggunakan tas punggung dengan berat lebih dari $10 \% \mathrm{BB}$ (Lisa, \& Ghozali, 2018). Hal ini terjadi karena banyaknya buku pelajaran yang harus dibawa, belum lagi jika siswa membawa bekal makanan atau minuman, tentunya beban tas akan semakin bertambah. Jika kondisi ini berlanjut, lama kelaman siswa akan mulai merasakan nyeri atau keluhan nyeri otot pada punggung atau sering disebut Musculoskeletal Disorders (MSDs).

Musculoskeletal Disorders (MSDs) adalah sekumpulan gejala atau gangguan yang berkaitan dengan jaringan otot, tendon, ligament, kartilago, sistem saraf, struktur tulang, dan pembuluh darah. MSDs pada awalnya menyebabkan sakit, nyeri, mati rasa, kesemutan, bengkak, kekakuan, gemetar, gangguan tidur dan rasa terbakar (Surya, Nirawan, \& Ihwan, 2018). Bila seseorang merasakan gejala-gejala seperti terasa kaku pada punggung dan leher; nyeri pada bahu, ataupun kehilangan fleksibilitas, tangan dan kaki terasa nyeri seperti tertusuk; siku ataupun sakit pada mata kaki, bengkak dan kaku; jari menjadi kehilangan mobilitasnya, terasa kaku dan kehilangan kekuatan; merasa kesemutan pada tumit dan kaki, dingin, kaku ataupun sensasi rasa panas,maka besar kemungkinan orang tersebut mengalami gangguan muskuloskeletal (Musculoskeletal Disorders/ MSDs) yaitu gangguan pada otot, tendon, sendi, ruas tulang belakang, dan saraf.

Keluhan sistem musculoskeletal pada umumnya terjadi karena kontraksi otot yang berlebihan akibat pemberian beban kerja yang terlalu berat dengan durasi pembebanan yang panjang. Sebaliknya, keluhan otot kemungkinan tidak terjadi apabila kontraksi otot hanya berkisar antara $15-20 \%$ dari kekuatan otot maksimum. Namun, apabila kontraksi otot melebihi $20 \%$, maka peredaran darah ke otot berkurang menurut tingkat kontraksi yang dipengaruhi oleh besarnya tenaga yang diperlukan. Suplai oksigen ke otot menurun, proses metabolisme karbohidrat terhambat dan sebagai akibatnya terjadi penimbunan asam laktat yang menyebabkan timbulnya rasa nyeri otot (Suwanto, Tarwaka, \& Werdani, 2016).

Penelitian di Polandia menunjukkan bahwa lebih dari $70 \%$ remaja berusia 10-19 tahun mengalami nyeri punggung (Kędra, \& Czaprowski, 2013). Penelitian di Iran menunjukkan bahwa prevalensi gejala nyeri leher, bahu, punggung bawah, dan punggung atas masing-masing adalah $27,9 \%, 20,7 \%, 34,3 \%$ dan $19,0 \%$. (Dianat et al., 2018).

Rekomendasi mengenai berat ransel sekolah dalam kaitannya dengan berat badan berbeda tergantung pada organisasi. Pada 2009, American Occupational Therapy Asosiasi (AOTA) dan American Physical Therapy Association (APTA) merekomendasikan untuk tidak membawa ransel lebih berat dari 15\% (atau antara 10\% dan 20\%) dari berat badan siswa. Pada 2012, aturan ini diubah menjadi $10 \%$ dari tubuh mereka berat (Dewi, \& Widyastuti, 2016). American Chiropractic Association (ACA) merekomendasikan agar berat ransel tidak melebihi $5-10 \%$ dari berat badan anak. Ada bahaya beban berlebihan untuk tulang punggung. Berat ransel sekolah seharusnya tidak melebihi $10 \%$ dari berat badan anak karena dapat mempengaruhi postur tulang belakang mereka, bentuk kaki, dan gaya berjalan (Kistner, Fiebert, 
Roach, \& Moore, 2013; Arias, Apolinário, Troster, Chimello, Carbone, \& Gimenes, 2019; Hong, Fong, \& Li, 2011; Drzał-Grabiec, Snela, Rachwał, Rykała, \& Podgórska, 2013).

Pelayanan kesehatan primer di Australia, menyebutkan data bahwa sebanyak 5,8 dari 100 anak-anak berusia kurang dari 18 tahun terindikasi mengalami musculoskeletal disorder. Dapat diestimasikan bahwa terdapat 880.000 masalah musculoskeletal pada anak-anak dan remaja per tahunnya di Australia (Rahmi, 2020). Di Indonesia sendiri, belum ada data nasional terkait prevalensi musculoskeletal disorder. Penelitian di Denpasar menunjukkan bahwa sebanyak $36,04 \%$ siswa SMA yang diteliti mengalami musculoskeletal disorders (Lestari, Purba, \& Tribuwono, 2020).

Selain dampak kesehatan fisik ada dampak psikologis akibat dari kondisi nyeri otot tersebut, seperti waktu sekolah yang hilang (Seth, Hicks, Uchida, Habib, Dembia, Dunne, \& Delp, 2018). Nyeri musculoskeletal yang tidak hilang meningkatkan resiko kecacatan dan dikaitkan dengan penurunan kekuatan otot, penurunan rentang masalah gerak, dan keseimbangan (Anggraini, \& Hendrati, 2014).

Penelitian sebelumnya menunjukkan bahwa muskuloskeletal disorder dapat mempengaruhi faktor psikososial pada remaja yaitu kecemasan/depresi, kejadian negatif, dan stres terkait sekolah adalah faktor yang paling penting (Eckhoff \& Kvernmo, 2014). Kondisi nyeri otot dapat menyebabkan gangguan kegiatan seharihari, seperti waktu sekolah yang hilang. Efek jangka panjangnya adalah memiliki implikasi terhadap akademik kesuksesan dan kesuksesan sosial di masa depan (Festy, 2018).

Beberapa faktor yang menyebabkan MSDs adalah peregangan otot yang berlebihan, aktivitas berulang, sikap kerja tidak alamiah (Sari, \& Rifai, 2019). Mengangkat beban berat seperti tas dapat menjadi salah satu faktor penyebab gangguan MSDs (Nugroho, 2019). Secara fisiologis perempuan lebih berisiko mengalami musculoskeletal disorder dibandingkan laki-lakl (Lestari, Purba, \& Tribuwono, 2020). Penelitian ini bertujuan untuk mengetahui seberapa besar perbedaan berat tas Siswa SMA berpengaruh terhadap risiko musculoskeletal disorder.

\section{METODE PENELITIAN}

Penelitian analitik observasional dengan desain cross sectional: Penelitian ini dilakukan pada bulan Maret - Oktober 2019. Populasinya berjumlah 4.708 siswa. sampel sejumlah 370 siswa. Siswa yang dijadikan sampel adalah siswa kelas XI. Metode pengambilan sampel dengan simple random sampling. Penelitian ini telah lolos komite etik dengan nomor ethical clearance 232 / KEPKPOLKESMA/ 2019.

Instrumen dalam penelitian ini adalah kuesioner Nordic Body Map merupakan metode penilaian yang sangat subjektif artinya keberhasilan aplikasi metode ini sangat tergantung dari kondisi dan situasi yang dialami pekerja pada saat dilakukannya. Untuk memperoleh gambaran gejala MSDs dapat menggunakan metode Nordic Body Map. Penelitian dan juga tergantung dari keahlian dan pengalaman observer yang bersangkutan. Kuesioner Nordic Body Map ini telah secara luas digunakan oleh para ahli ergonomi untuk menilai tingkat keparahan gangguan pada sistem muskuloskeletal dan mempunyai validitas dan reabilitas yang cukup (Tarwaka, 2010; Hayati, 2014) .

Klasifikasi subjektivitas tingkat resiko otot skeletal berdasarkan total skor individu, dan data berat tas siswa SMA. Terdapat 28 bagian tubuh yang ditanyakan kaitannya dengan keluhan musculoskeletal disorder. Skala pengukuran yang digunakan adalah skala Guttman, yaitu terdiri atas dua pilihan jawaban, ada keluhan (ya) dan tidak ada keluhan musculoskeletal disorder. Kuesioner telah teruji validitas dan reliabilitasnya Skor terendah 28.00 dan skor tertinggi 108.00. Teknik pengumpulan data yaitu dengan pengisian kuesioner (angket) untuk variabel terikat dan observasi yaitu dengan menimbang berat tas para siswa dengan menggunakan timbangan digital. Sebelum responden mengisi kuesioner, peneliti memberikan penjelasan sebelum persetujuan kemudian responden akan mengisi surat pernyataan persetujuan. Analisis data dilakukan secara univariat dan bivariat dengan menggunakan uji Korelasi Spearman. 
HASIL

Tabel 1. Karakteristik Demografi Responden N=370

\begin{tabular}{|c|c|c|c|}
\hline Karakteristik Demografi Responden & $\mathbf{N}$ & $\%$ & MESD \\
\hline Umur (Tahun) (Rentang: 15-17 Tahun) & 370 & 100 & $16.44 \pm 0.52$ \\
\hline Jarak Tempuh (KM) (Rentang: 1-3 Km) & 370 & 100 & $2.02 \pm 0.805$ \\
\hline Berat Tas $(\mathrm{Kg})$ (Rentang: $0.20-11.50 \mathrm{Kg}$ ) & 370 & 100 & $3.74 \pm 1.57$ \\
\hline \multicolumn{4}{|l|}{ Jenis Kelamin: } \\
\hline $\begin{array}{l}\text { Laki-laki } \\
\text { Perempuan }\end{array}$ & $\begin{array}{l}164 \\
206\end{array}$ & $\begin{array}{l}44.30 \\
55.70\end{array}$ & \\
\hline $\begin{array}{l}\text { Jenis Tas: } \\
\text { Ransel } \\
\text { Slempang/jinjing } \\
\text { Keduanya }\end{array}$ & $\begin{array}{c}350 \\
12 \\
8\end{array}$ & $\begin{array}{c}94.60 \\
3.20 \\
2.20\end{array}$ & \\
\hline Prestasi Belajar Siswa (Rentang: 75.30-86.00) & 370 & 100 & $81.03 \pm 1.80$ \\
\hline Skor Keluhan Nyeri Otot (Rentang: 28-108) & 370 & 100 & $36.25 \pm 8.99$ \\
\hline \multicolumn{4}{|l|}{ Keluhan Nyeri Otot } \\
\hline $\begin{array}{l}\text { Ada keluhan } \\
\text { Tidak ada keluhan }\end{array}$ & $\begin{array}{l}334 \\
36\end{array}$ & $\begin{array}{c}90.30 \\
9.70\end{array}$ & \\
\hline \multicolumn{4}{|l|}{ IMT } \\
\hline Kekurangan BB Tingkat Berat $(<17,00)$ & 32 & 8.6 & \\
\hline Kekurangan BB Tingkat Ringan $(17,0-18,40)$ & 50 & 13.5 & \\
\hline Normal $(18,5-25,0)$ & 228 & 61.6 & \\
\hline Kelebihan BB Tingkat Ringan $(25,1-27,0)$ & 28 & 7.6 & \\
\hline Kelebihan BB Tingkat Berat $(>27,0)$ & 32 & 8.6 & \\
\hline
\end{tabular}

Usia responden minimum 15, maximum 17 tahun, dengan mean 16.44 dan standar deviasi 0.52 . Sebagian besar responden berjenis kelamin perempuan (55.7\%), jarak tempuh responden minimum 1 , maximum 3 kilometer, dengan mean 2.02 dan standar deviasi 0.805 . Berat tas yang selalu dibawa kesekolah responden minimum $0.20 \mathrm{Kg}$, maximum $11.50 \mathrm{Kg}$, dengan mean 3.74 dan standar deviasi 1.57 . Jenis tas yang biasa dipakai sebagiab besar menggunakan tas ransel $(94.60 \%)$.

Prestasi belajar responden minimum 75.30, maximum 86.00, dengan mean 81.03 dan standar deviasi 1.80. Skor keluhan nyeri otot menggunakan metode Nordic Body Map. Minimum 28, maximum 108, dengan mean 26.25 dan standar deviasi 8.99 dan sebagian besar mempuntai keluhan sebanyak (90.30\%). Dilihat dari IMT, responden terbanyak memiliki status gizi normal $(61,6 \%)$.

Yunita Sari Purba ${ }^{1 *}$, Putri Winda Lestari ${ }^{2}$

'Prodi Keselamatan dan Kesehatan Kerja, Fakultas Kesehatan Masyarakat, Universitas Binawan

E-mail: yunita@binawan.ac.id', winda@binawan.ac.id 


\section{Grafik 1.}

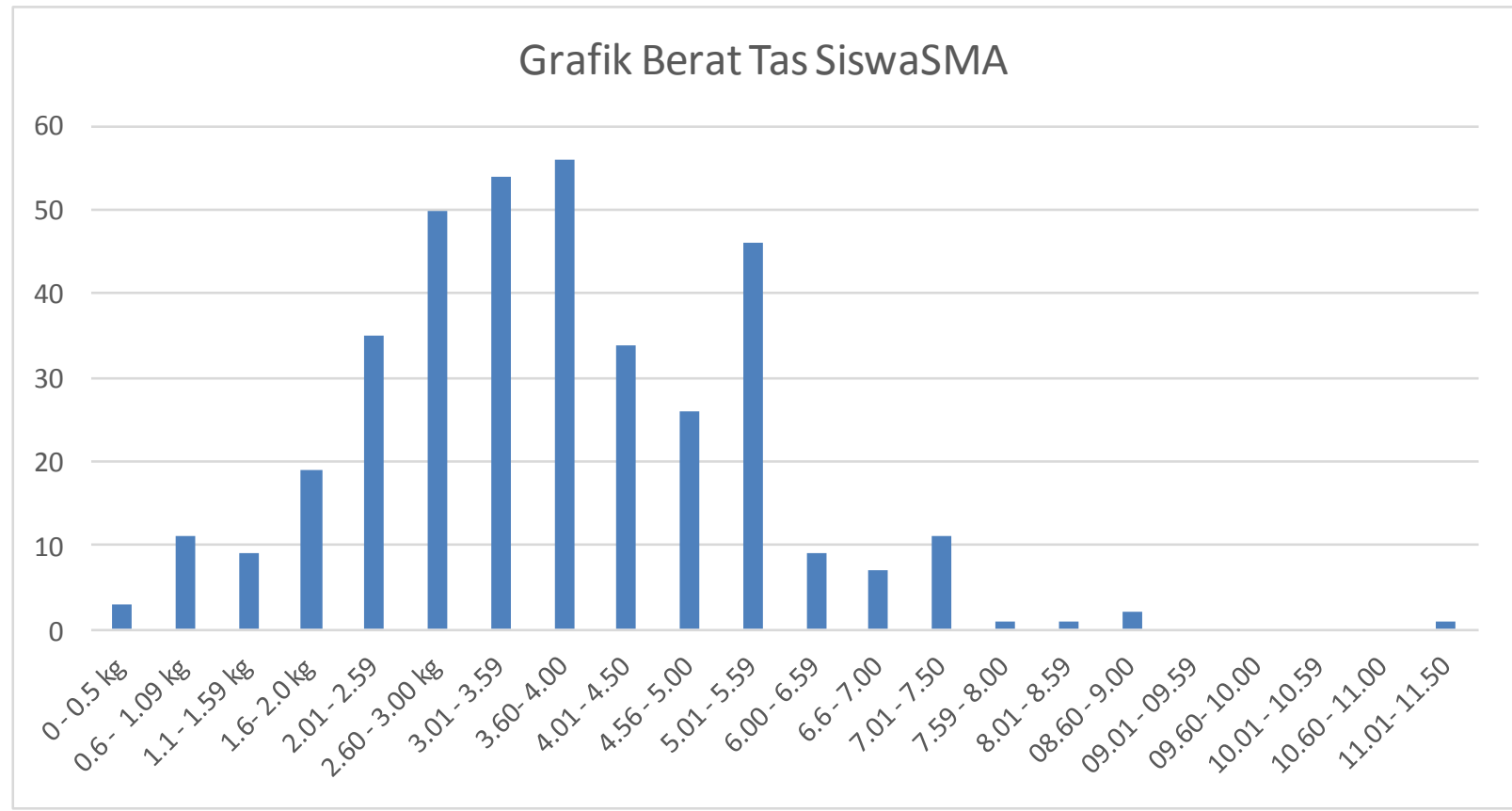

Grafik 1. Mengidentifikasikan beban berat tas yang dibawa responden kesekolah setiap hari. Grafix 2. Menjelaskan pada anggota tubuh yang paling banyak mengalami nyeri otot pada siswa SMA adalah bahu kanan $(49,73 \%)$, punggung $(49,19 \%)$, pinggang $(38,92 \%)$ dan leher atas $(37,84 \%)$. Sedangkan anggota tubuh yang paling sedikit mengalami keluhan nyeri otot adalah siku kiri $(7,03 \%)$, siku kanan $(7,84 \%)$, pantat (bottom) $(9,73 \%)$, tangan kiri $(11,08 \%)$ dan lengan bawah kiri $(11,62 \%)$.

\section{Grafik 2.}

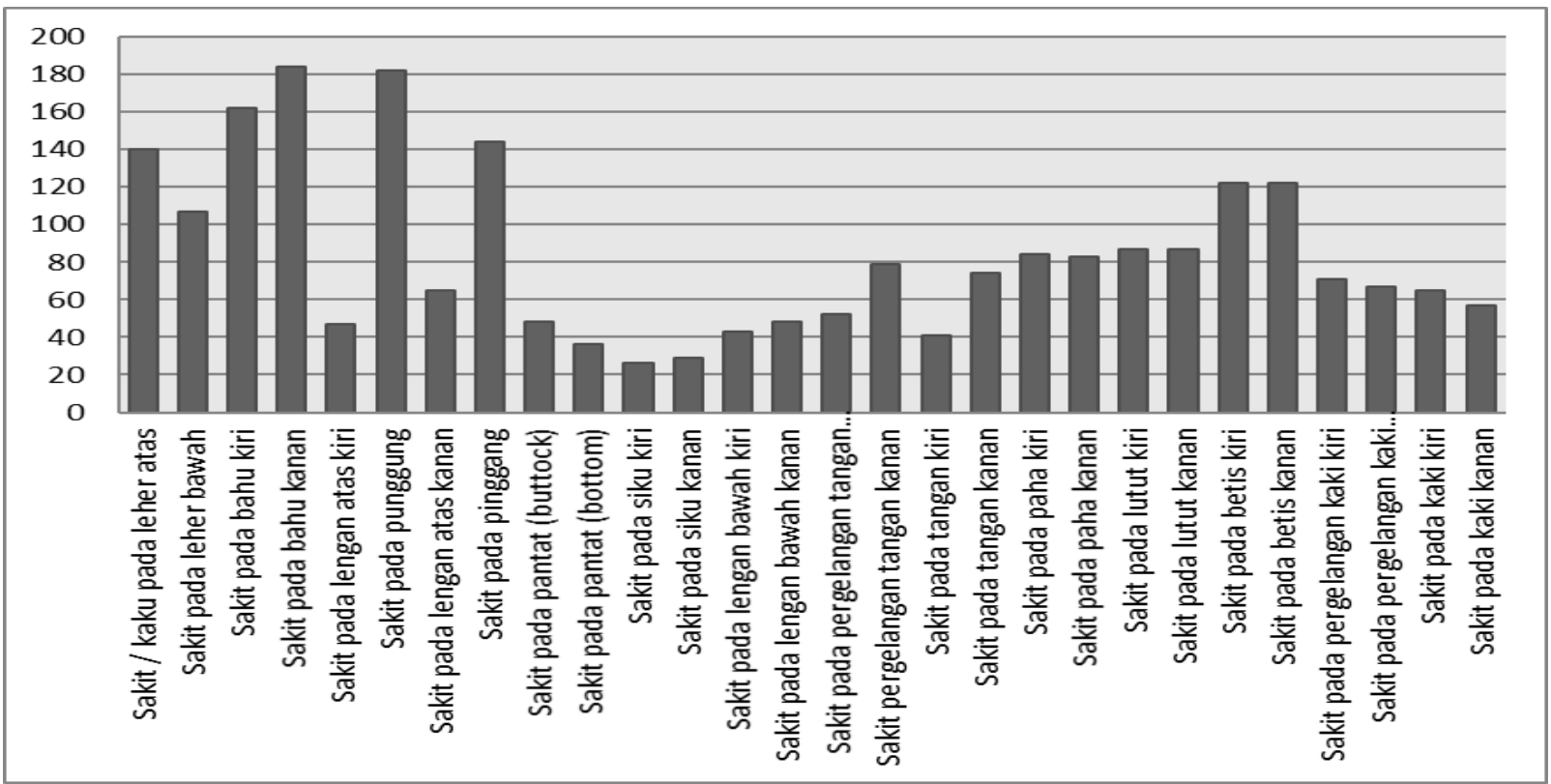

Yunita Sari Purba ${ }^{1 *}$, Putri Winda Lestari ${ }^{2}$

'Prodi Keselamatan dan Kesehatan Kerja, Fakultas Kesehatan Masyarakat, Universitas Binawan

E-mail: yunita@binawan.ac.id', winda@binawan.ac.id 
Pengaruh berat beban tas dengan keluhan musculoskeletal pada siswa SMA

Tabel 2. Hasil Analisis Korelasi Spearman

\begin{tabular}{lcccc}
\hline Variabel & Mean & $S D$ & $p$-value & $r$ \\
\hline Berat Tas Dengan Nyeri Otot & 3.74 & 1.57 & 0,000 & 0,225 \\
Jenis Tas Dengan Nyeri Otot & & & 0,063 & \\
$\begin{array}{l}\text { Keluhan Nyeri Otot Dengan Prestasi } \\
\text { Belajar }\end{array}$ & 36.25 & 8.99 & 0,001 & 0,170 \\
\hline
\end{tabular}

Berdasarkan uji korelasi Spearman didapatkan nilai $p=0,000$ dengan nilai $r=0,225$ yang artinya terdapat korelasi yang lemah antara berat tas dengan keluhan nyeri otot. Arah korelasi positif menunjukkan bahwa semakin berat tas maka keluhan nyeri otot makin tinggi, begitu juga sebaliknya. Semakin ringan tas maka keluhan nyeri otot makin rendah.

\section{PEMBAHASAN}

Berdasarkan hasil penelitian yang dilakukan di Jakarta pada tahun 2019 ini, diperoleh data dari total responden 370 siswa, 164 siswa $(44,30 \%)$ berjenis kelamin laki-laki dan 206 siswa $(55,70 \%)$ berjenis kelamin perempuan. Sebagian besar siswa (350 siswa) dengan persentase 94,60\% menggunakan tas ransel, 12 siswa $(3,20 \%)$ menggunakan tas jinjing/selempang dan 8 siswa $(2,20 \%)$ menggunakan kedua jenis tas, sedangkan beban berat tas yang dibawa para siswa siswa menunjukkan bahwa rata-rata beban tas yang dibawa siswa adalah $3,74 \mathrm{~kg}$ atau sekitar 7,18\% dari berat badan rata-rata siswa. Dimana beban terendah adalah 0,20 gram dan beban tas tertinggi adalah $11,5 \mathrm{~kg}$. Namun terdapat $16,76 \%$ siswa yang masih membawa beban tas melebihi 10\% dari berat badan mereka. Di Australia, beban ratarata yang dibawa oleh anak-anak adalah $5,3 \mathrm{~kg}$ atau sekitar $10 \%$ dari berat badan rata-rata mereka (Kistner, Fiebert, Roach, \& Moore, 2013). Dalam sebuah penelitian di Amerika Serikat, berat ratarata tas sekolah adalah $17 \%$ dari berat siswa (Drzał-Grabiec, 2013). Survei yang dilakukan pada 529 anak-anak di Irlandia dan menemukan bahwa berarti berat tas sekolah adalah $12,6 \%$ dari berat siswa, dan hanya $29,9 \%$ anak-anak membawa tas sekolah itu kurang dari atau sama dengan 10\% dari berat siswa (Dockrell, Simms, \& Blake, 2015). Sedangkan beban rata-rata dipikul oleh anak sekolah Italia adalah $22,0 \%$ dari berat siswa (Merati, Negrini, Carabalona, Margonato \& Veicsteinas, 2004).

Penelitian ini menunjukkan bahwa terdapat korelasi antara berat tas dengan keluhan nyeri otot. Penelitian sebelumnya menunjukkan bahwa tekanan fisik harian terkait membawa ransel menyebabkan perubahan kelengkungan tulang belakang. (Orloff \& Rapp, 2004; Chow, Ting, Pope, \& Lai, 2009) Peningkatan beban ransel secara signifikan memampatkan ketinggian lumbar disk yang diukur di bidang sagital garis tengah. Adaptasi postural intermiten harian diasumsikan mengakibatkan rasa sakit dan cacat pada anak sekolah (Harrison, Fecht, Brunt, \& Neuschwander-Tetri, 2009; Manuntung, 2019). Beban ransel yang berlebihan menyebabkan sakit punggung dan kelainan tulang belakang di anakanak (Fitriani, 2016).

Beban tas sekolah yang berat, menghasilkan beberapa postur perubahan di kepala dan batang menempatkan jaringan lunak. Beban ransel melebihi $10 \%$ dari tubuh berat badan telah terbukti meningkatkan konsumsi energi, meningkatkan lean condong ke depan dan hasilnya dalam volume paru-paru menurun (Faghy, \& Brown, 2014). Tiga faktor inilah yang memimpin untuk mengurangi tekanan parsial oksigen $\left(\mathrm{PO}_{2}\right)$ yang menghasilkan respirasi anaerob dan akhirnya kelelahan (Mwaka et al., 2014).

Seorang anak yang membawa ransel berat akan cenderung membungkuk untuk menyeimbangkan pusat gravitasi mereka, yang menghasilkan pengurangan lordosis lumbal dan peningkatan kyphosis toraks (Mwaka et al., 2014). Postur seperti itu bisa menjadi kebiasaan dan dipertahankan bahkan setelah melepas ranselnya. Anak-anak biasanya membawa tas punggung mereka dalam periode singkat namun setiap hari.

Yunita Sari Purba ${ }^{1 *}$, Putri Winda Lestari ${ }^{2}$

'Prodi Keselamatan dan Kesehatan Kerja, Fakultas Kesehatan Masyarakat, Universitas Binawan

E-mail: yunita@binawan.ac.id', winda@binawan.ac.id 
Penelitian dari sebelumnya menunjukkan dari 62 responden, berat tas paling banyak ada pada kategori berat ( $\geq 15 \%$ dari berat badan) yang mengalami nyeri punggung bawah sebanyak 24 orang $(38.7 \%)$ dan yang tidak mengalami nyeri punggung bawah paling banyak ada pada kategori berat tas sedang (10-14\% dari berat badan) sebanyak 11 orang sebesar 17,7\% (Mahendrayani, Purnawati, \& Andayani, 2014).

Sejalan dengan penelitian sebelumnya menyatakan bahwa dari Berat beban yang diangkat tubuh secara berlebihan dapat menimbulkan cedera pada otot dan tulang hal itu karena beban berat yang dipikul dapat mengurangi ketebalan dari interverbal disc atau elemen yang berada diantara tulang belakang. terdapat hubungan yang signifikan antara berat tas dengan keluhan muskuloskeletal. (Legiran, et.al., 2018)

Penelitian ini diperkuat juga dengan penelitian sebelumnya menunjukan bahwa resiko seseorang mengalami keluhan nyeri bahu jika menggunakan tas dengan kategori berat adalah 1,4 kali lebih tinggi dibanding jika menggunakan tas dengan kategori ringan. Hasil lain yang didapat adalah confidence interval $(\mathrm{Cl})$ dengan rentangan 1,162- 1,728, yang menunjukkan estimasi rentang nilai pada populasi (Dewantari, \& Adiputra, 2017)

Sebanyak $90,30 \%$ siswa yang menjadi subyek penelitian menyatakan bahwa mereka memiliki keluhan nyeri otot. Keluhan nyeri otot tertinggi adalah pada bagian bahu dan punggung. Penelitian lain menyatakan bahwa sebagian besar anak-anak yang membawa ransel mengalami low back pain dan sakit di bagian atas tubuh yang melibatkan leher, bahu dan punggung atas. Rasa sakit di daerah ini dikaitkan dengan membawa beban berat (Yusoff, 2013).

\section{SIMPULAN}

Dari hasil penelitian dapat disimpulkan bahwa ada pengaruh antara berat tas dengan kejadian musculoskeletal disorder, terdapat korelasi yang lemah antara berat tas dengan keluhan nyeri otot dengan arah korelasi positif ( $p=0,000$ dengan nilai $r=0,225)$, artinya semakin berat tas yang dibawa oleh para siswa maka keluhan nyeri otot yang dialami akan semakin tinggi, begitu juga sebaliknya, semakin ringan tas maka keluhan nyeri otot makin rendah.

\section{SARAN}

Tindakan perbaikan yang dapat dilakukan adalah sekolah menyediakan fasilitas locker bagi para siswa untuk menyimpan sebagian buku-buku pelajaran sehingga siswa tidak perlu membawa buku yang banyak dalam tas mereka, buku cetak disimpan di sekolah dan dibagikan ketika ada mata pelajarannya, serta memberikan edukasi atau penyuluhan kepada siswa terkait faktor risiko musculoskeletal disorder dan yang lebih penting lagi memeriksakan siswa yang mengalami nyeri yang parah ke dokter untuk penanganan lebih dini agar tidak menjadi lebih parah dan dapat dilakukan tindakan pengobatan atau pencegahan sesuai dengan arahan dari dokter yang bersangkutan.

\section{DAFTAR PUSTAKA}

American Chiropractic Association. (2018). Backpack misuse leads to chronic back pain, doctors of chiropractic say Available from: https://www. acatoday. org/Patients/HealthWellness-Information. Backpack-Safety, accessed on November 9th.

Anggraini, N. E., \& Hendrati, L. Y. (2014). Hubungan Obesitas dan Faktor-Faktor Pada Individu dengan Kejadian Osteoarthritis Genu. Jurnal Berkala Epidemiologi, 2(1), 93104.

Chow, D. H. K., Ting, J. M. L., Pope, M. H., \& Lai, A. (2009). Effects of backpack load placement on pulmonary capacities of normal schoolchildren during upright stance. International journal of industrial ergonomics, 39(5), 703-707.

Dewantari, L. P. A., \& Adiputra, I. N. (2017). Hubungan berat tas punggung dengan keluhan nyeri punggung bawah, nyeri bahu dan nyeri leher pada siswa sd di kecamatan kuta, badung. E-Jurnal Medika, 6(2), 1-11.

Dewi, I. G. A. P. A., \& Widyastuti, I. A. P. (2016). Gambaran Perubahan Postur Tubuh pada Siswa Sekolah Menengah Pertama (SMP) Akibat Penggunaan Tas Punggung Berat. Coping: Community of Publishing in Nursing, 4(2), 6-12. 
Dockrell, S., Simms, C., \& Blake, C. (2015). Schoolbag carriage and schoolbag-related musculoskeletal discomfort among primary school children. Applied Ergonomics, 51, 281 290.

Drzał-Grabiec, J. (2013). o stopniach naukowych i tytule naukowym oraz o stopniach i tytule w zakresie sztuki (Dz. U. nr 65, poz. 595 ze zm.). Spine, 38(20), 1785-1789.

Drzał-Grabiec, J., Snela, S., Rachwał, M., Rykała, J., \& Podgórska, J. (2013). Effects of carrying a backpack in a symmetrical manner on the shape of the feet. Ergonomics, 56(10), 15771583.

Eckhoff, C., \& Kvernmo, S. (2014). Musculoskeletal pain in Arctic indigenous and non-indigenous adolescents, prevalence and associations with psychosocial factors: a population-based study. BMC Public Health, 14(1), 617.

Faghy, M. A., \& Brown, P. I. (2014). Thoracic load carriage-induced respiratory muscle fatigue. European journal of applied physiology, 114(5), 1085-1093.

Festy, P. (2018). Lanjut Usia Perspektif dan Masalah. UMSurabaya Publishing.

Fitriani, C. D., (2016). Hubungan Penggunaan Backpack Dengan Keluhan Nyeri Punggung Pada Siswa Di Smp Bina Karya Surabaya.

Hayati, S. W. N. (2014). Hubungan Risiko Postur Kerja Berdasarkan Metode Reba Dengan Keluhan Muskuloskeletal Karyawan Unit Kantin Di Pt. Indo Acidatama Tbk. Kemiri, Kebakkramat, Karanganyar.

Harrison, S. A., Fecht, W., Brunt, E. M., \& Neuschwander-Tetri, B. A. (2009). Orlistat for overweight subjects with nonalcoholic steatohepatitis: a randomized, prospective trial. Hepatology, 49(1), 80-86.

Hong, Y., Fong, D. T. P., \& Li, J. X. (2011). The effect of school bag design and load on spinal posture during stair use by children. Ergonomics, 54(12), 1207-1213.
Kędra, A., \& Czaprowski, D. (2013). Epidemiology of back pain in children and youth aged 10-19 from the area of the southeast of Poland. BioMed research international, 2013.

Kistner, F., Fiebert, I., Roach, K., \& Moore, J. (2013). Postural compensations and subjective complaints due to backpack loads and wear time in schoolchildren. Pediatric Physical Therapy, 25(1), 15-24.

Legiran, L., Suciati, T., \& Pratiwi, M. R. (2018). Hubungan antara penggunaan tas sekolah dan keluhan muskuloskeletal pada siswa sekolah dasar. Jurnal Kedokteran dan Kesehatan: Publikasi IImiah Fakultas Kedokteran Universitas Sriwijaya, 5(1), 1-9.

Lestari, P. W., Purba, Y. S., \& Tribuwono, A. C. (2020). Comparison of Musculoskeletal Disorder Risk based on Gender in High School Students. KEMAS: Jurnal Kesehatan Masyarakat, 16(1), 53-60.

Lisa, M., \& Ghozali, G. (2018). Hubungan antara Berat Beban Tas Punggung dengan Keluhan Nyeri Punggung Bawah, Nyeri Bahu dan Nyeri Leher pada Siswa di Madrasah Aliyah Negeri 2 Samarinda.

Mahendrayani, L. I., Purnawati, S., \& Andayani, N. (2014). The Hubungan Berat Tas Dengan Nyeri Punggung Bawah Pada Anak Sekolah Umur 12-14 Tahun Di Denpasar. Majalah IImiah Fisioterapi Indonesia, 3(1).

Manuntung, N. A., \& Kep, M. (2019). Terapi perilaku kognitif pada pasien hipertensi. Wineka Media.

Merati, G., Negrini, S., Carabalona, R., Margonato, V., \& Veicsteinas, A. (2004). Trunk muscular strength in pre-pubertal children with and without back pain. Pediatric Rehabilitation, 7(2), 97-103.

Mwaka, E. S., Munabi, I. G., Buwembo, W., Kukkiriza, J., \& Ochieng, J. (2014). Musculoskeletal pain and school bag use: a cross-sectional study among Ugandan pupils. BMC research notes, 7(1), 222.

Yunita Sari Purba ${ }^{1 *}$, Putri Winda Lestari ${ }^{2}$

'Prodi Keselamatan dan Kesehatan Kerja, Fakultas Kesehatan Masyarakat, Universitas Binawan

E-mail: yunita@binawan.ac.id', winda@binawan.ac.id 
Navuluri, N., \& Navuluri, R. B. (2006). Study on the relationship between backpack use and back and neck pain among adolescents. Nursing \& health sciences, 8(4), 208-215.

Nugroho, D. V. P. (2019). Hubungan Berat Tas Punggung dengan Keluhan Nyeri Punggung Bawah (Low Back Pain) pada Murid Kelas 4-6 di SD Muhammadiyah 9 Malang (Doctoral dissertation, University of Muhammadiyah Malang).

Nurhaliza, D. (2020). Upaya Perawat Untuk Mempertahankan Posisi Ergonomis Dan Mencegah Hazard Psikososial Pada Pasien Di Rumah Sakit.

Orloff, H. A., \& Rapp, C. M. (2004). The effects of load carriage on spinal curvature and posture. Spine, 29(12), 1325-1329.

Rahmi, S. A. (2020). Analisis Faktor Sedentary Lifestyle Dan Konsumsi Jajanan Terhadap Kejadian Stunted Obesity Pada Anak Sekolah Dasar Di Kabupaten Magelang (Doctoral dissertation, Universitas Negeri Semarang).

Sari, R. O., \& Rifai, M. (2019). Hubungan Postur Kerja Dan Masa Kerja Dengan Keluhan Musculoskeletal Disorders (Msds) Pada Pembatik Giriloyo Di Kabupaten Bantul (Doctoral dissertation, Universitas Ahmad Dahlan).
Seth, A., Hicks, J. L., Uchida, T. K., Habib, A., Dembia, C. L., Dunne, J. J., \& Delp, S. L. (2018). OpenSim: Simulating musculoskeletal dynamics and neuromuscular control to study human and animal movement. PLOS computational biology, 14(7), e1006223.

Surya, R. Z., Nirawan, D., \& Ihwan, K. (2018). Investigasi Musculoskeletal Disorders (MSDs) Pada Aktivitas Panen Kelapa Desa Simpang Jaya Dusun Benteng Makmur Rt 12 Rw 04 Kecamatan Batang TuakA. JUTI UNISI, 2(1).

Suwanto, J., Tarwaka, P., \& Werdani, K. E. (2016). Hubungan Antara Risiko Postur Kerja Dengan Risiko Keluhan Muskuloskeletal Pada Pekerja Bagian Pemotongan Besi Di Sentra Industri Pande Besi Padas Klaten (Doctoral dissertation, Universitas Muhammadiyah Surakarta).

Yusoff, M. I. B. (2013). Hubungan Penggunaan Tas Jenis Ransel dan Jenis Troli Terhadap Kejadian Nyeri Punggung pada Siswa Sekolah Dasar Yayasan Pendidikan Shafiyyatul Amaliyyah, Medan. 